\title{
ANALISIS HARGA SAHAM SEKTOR ANEKA INDUSTRI YANG TERDAFTAR DI BURSA EFEK INDONESIA
}

\author{
Nadhifah $^{1}$; Ediwarman²; Dewi Cahyani Pangestuti ${ }^{3}$ \\ Universitas Pembangunan Nasional Veteran Jakarta \\ 1Email: nadhifah47@upnvj.ac.id; ;2Email: ediwarman@upnvj.ac.id; ${ }^{3}$ Email: dewichepe@upnvj.ac.id \\ http://dx.doi.org/10.21460/jrak.2021.172.404
}

\begin{abstract}
ABSTRAK
Penelitian ini bertujuan untuk menilai pengaruh Profitabilitas, Likuiditas dan Leverage terhadap Harga Saham. Populasinya seluruh perusahaan sektor aneka industri yang terdaftar di Bursa Efek Indonesia. Dengan menggunakan metode purposive sampling didapat 22 perusahaan sektor aneka industri dengan periode empat tahun penelitian sehingga memperoleh 88 data. Teknik analisis data yang digunakan adalah Analisis Regresi Data Panel dengan bantuan Eviews 11 menggunakan signifikansi 5\%. Penelitian ini menunjukkan hasil bahwa Profitabilitas yang diukur dengan Return on Equity (ROE) berpengaruh positif terhadap Harga Saham, Likuiditas yang diukur dengan Current Ratio (CR) tidak berpengaruh terhadap Harga saham dan Leverage yang diukur dengan Debt to Equity Ratio (DER) berpengaruh positif terhadap Harga Saham.
\end{abstract}

Kata Kunci : harga saham; profitabilitas; likuiditas; leverage

\begin{abstract}
This study aimed to assess the effect of Probability, Liquidity and Leverage on Stock Price. The population is all Miscellaneous Industry Sector Companies Listed in Indonesia Stock Exchange. By using Purposive Sampling method, obtained 22 companies in the Miscellaneous Industry Sector with a research period of four years to obtain 88 data. Data analysis technique by using Panel Data Regression Analysis with Eviews 11 and significant 5\%. This study shows the results that profitability as measured by Return on Equity (ROE) has a positive effect on Stock Price, Liquidity as measured by Current Ratio (CR) has no effect on Stock Price and Leverage as measured by Debt to Equity Ratio (DER) has a positive effect on Stock Price.
\end{abstract}

Keywords : stock price; profitability; liquidity; leverage

\section{PENDAHULUAN}

Dalam perkembangan globalisasi sekarang, banyak perusahaan melakukan persaingan dengan perusahaan lain yang terus berkembang dengan cepat. Saat perusahaan tersebut tidak dapat bertahan dalam persaingan yang ada maka akan tergantikan posisinya oleh perusahaan yang lebih maju. Hal ini memaksakan setiap perusahaan di berbagai sektor untuk terus menaikkan kinerja perusahaannya supaya dapat bersaing dengan perusahaan lain secara global.

Sektor aneka industri menjadi bagian dari banyaknya sektor yang melakukan persaingan bisnis. Sektor aneka industri ini terdiri atas enam sub sektor diantaranya sub sektor mesin dan alat berat, otomotif dan komponen, tekstil dan garmen, alas kaki, kabel, dan elektronika. Dalam siaran pers Kemenperin.go.id menyebutkan bahwa sub sektor tekstil dan 
garmen, otomotif serta elektronika menjadi sektor andalan yang mendapat prioritas pengembangannya dalam mendukung industri era 4.0 karena berperan terhadap pertumbuhan ekonomi nasional dengan berkontribusi sebesar 60 persen dalam Produk Domestik Bruto. Dengan menjadi sektor prioritas diharapkan sektor aneka industri dapat membangun ekonomi nasional yang kokoh serta dapat memunculkan peluang investor untuk melakukan investasi.

Investasi yang paling popular dan banyak diminati kalangan investor salah satunya saham. Saham ialah surat bukti penanaman modal pada perusahan yang secara langsung menjadi bukti kepemilikan perusahan tersebut (Sudana, 2015, p. 204). Saat melakukan investasi, para investor akan berharap memperoleh tingkat pengembalian yang besar agar dapat mensejahterakan hidup mereka dimasa depan. Namun, seiring bertambahnya tingkat pengembalian begitu juga dengan risiko yang didapat. Risiko yang akan dihadapi para investor salah satunya ialah perubahan harga saham. Menurut Aristanti \& Utiyati (2018) aspek yang dapat berpengaruh terhadap harga saham adalah aspek internal perusahaan seperti kinerja perusahaan, dividen yang dibayarkan, ekspansi perusahaan dan pergantian direksi sedangkan aspek eksternal perusahaan seperti kondisi pasar, ekonomi, politik negara, inflasi dan kurs mata uang.

Harga saham sebagai indikator utama untuk para investor dapat menentukan keputusan investasinya. Dengan memaksimalkan harga saham dapat mensejahterakan investor karena harga saham dapat menggambarkan nilai perusahaan (Tricia, Surachim, \& Tarmedi, 2018). Apabila perusahaan mampu menghasilkan kinerja yang baik akan berdampak pada tingginya peminat saham tersebut serta membuat harga saham meningkat dan return saham persahaan tersebut tentu akan meningkat. Berikut disajikan data rerata profitabilitas, likuiditas dan leverage perusahaan aneka industri periode 2016-2020:

Tabel 1. Rata-rata Profitabilitas, Likuiditas dan Leverage

\begin{tabular}{ccccccccc}
\hline Tahun & $\begin{array}{c}\text { Return } \\
\text { Saham }\end{array}$ & $\begin{array}{c}\text { Naik/ } \\
\text { (Turun) }\end{array}$ & $\begin{array}{c}\text { Profitabilitas } \\
(\%)\end{array}$ & $\begin{array}{c}\text { Naik/ } \\
\text { (Turun) }\end{array}$ & $\begin{array}{c}\text { Likuiditas } \\
(\mathrm{X})\end{array}$ & $\begin{array}{c}\text { (Naik)/ } \\
\text { Turun }\end{array}$ & $\begin{array}{c}\text { Leverage } \\
(\mathrm{X})\end{array}$ & $\begin{array}{c}\text { (Naik)/ } \\
\text { Turun }\end{array}$ \\
\hline 2016 & 0,299 & $-13,41$ & 4,14 & $-0,72$ & 1,44 & 0,18 & 1,55 & 0,09 \\
2017 & 0,388 & 0,09 & $-3,45$ & $-7,59$ & 1,54 & 0,1 & 3,59 & 2,04 \\
2018 & 0,612 & 0,22 & 8,80 & 12,25 & 1,54 & 0 & $-2,86$ & $-6,45$ \\
2019 & 0,015 & $-0,59$ & 4,67 & $-4,13$ & 1,93 & 0,39 & 0,34 & 3,2 \\
\hline
\end{tabular}

Sumber : www.idx.co.id

Dari tabel 1 diatas, dapat dilihat dalam tahun 2016-2019 profitabilitas perusahaan aneka industri mengalami fluktuasi naik dan turun. Penurunan profitabilitas mengindikasikan bahwa kemampuan perusahaan aneka industri dalam memperoleh laba bersih menurun. Hal tersebut berdampak pada menurunnya keinginan investor untuk berinvestasi saham tersebut karena tingkat pengembalian yang didapat oleh investor rendah sehingga dapat menurunkan harga saham. Pernyatan tersebut persis dengan teori menyatakan bahwa menurunnya profitabilitas akan menurunkan harga saham. Fenomena ini sependapat dengan penelitian Batubara et al. (2019), Rahayu et al. (2020) dan Saprudin \& Hasyim (2020) yang menyatakan profitabilitas berpengaruh positif terhadap harga saham. Namun, tidak sependapat dengan Hastuti \&
Sutanto (2017) yang menyatakan profitabilitas tidak berpengaruh terhadap harga saham.

Kemudian fenomena berikutnya, terlihat perusahaan aneka industri mengalami peningkatan likuiditas tetapi harga saham mengalami penurunan. Hal ini tidak sama dengan teori bahwa likuiditas yang tinggi akan membuat harga saham meningkat dikarenakan mampu menarik investor untuk berinvestasi (Widyaningrum \& Suwitho, 2020). Namun, fenomena ini sejalan oleh hasil penelitian Nurlia \& Juwari (2019) dan Andrean (2019) menyatakan likuiditas berpengaruh negatif signifikan terhadap harga saham dimana likuiditas yang meningkat membuat harga saham menurun. Lain halnya dengan hasil penelitian Latifah \& Suryani (2020) dan Widyaningrum \& Suwitho (2020) yang menyatakan likuiditas berpengaruh positif terhadap harga saham. Serta tidak sependapat 
dengan Adipalguna \& Suarjaya (2016), Otekunrin et al., (2018), Tricia et al. (2018), Lilie et al., (2019) dan Indrayani et al., (2020) menyatakan likuiditas tidak mempengaruhi harga saham.

Fenomena yang terakhir, terlihat pada perusahaan aneka industri mengalami peningkatan leverage yang dibarengi dengan penurunan harga saham. Hal tersebut tidak serupa dengan teori, dimana leverage yang semakin tinggi akan menurunkan harga saham. Fenomena ini didukung oleh penelitian Pangestuti \& Hamidi (2016) dan Natalia et al. (2020) mengatakan bahwa leverage yang tinggi menggambarkan semakin tinggi besaran hutang terhadap modal sendiri sehingga mengindikasikan peningkatan resiko, berdampak pada permintaan saham perusahaan menurun dan banyak investor yang menghindari perusahaan dengan leverage yang tinggi sehingga memicu penurunan harga saham. Sependapat dengan Hanie \& Saifi (2018), Azmy \& Lestari (2019) dan Tantri \& Djawoto (2019) yang menyatakan leverage berpengaruh positif terhadap harga saham. Namun, tidak sependapat dengan Priliyastuti \& Stella (2017) dan Wangarry et al. (2019) yang menyatakan leverage tidak berpengaruh terhadap harga saham.

Dari penjelasan di atas, penelitian ini perlu dilakukan sebab masih terdapat kesenjangan hasil penelitian yang telah dilakukan berkaitan dengan harga saham. Maka dari itu, didapat rumusan masalah seperti berikut: Apakah profitabilitas, likuiditas dan leverage berpengaruh terhadap harga saham?. Serta didapat tujuan dari penelitian sebagai berikut: untuk mengetahui pengaruh profitabilitas, likuiditas dan leverage terhadap harga saham.

\section{KAJIAN LITERATUR DAN PENGEMBANGAN HIPOTESIS}

\section{Signalling Theory}

Signalling theory biasa dikenal dengan teori sinyal yang telah disempurnakan oleh Ross pada tahun 1977 mengatakan setiap manajemen perusahaan yang mempunyai informasi lebih banyak tentang kualitas perusahaannya diharuskan mengirimkan informasi tersebut untuk calon pemodal supaya mereka mengetahui apa yang tidak dapat mereka amati dari kondisi keuangan perusahaan (Janiman,
2021). Informasi yang diberikan dapat dibedakan menjadi informasi baik yang menjadi sinyal positif dan informasi buruk yang akan menjadi sinyal buruk (Setiawanta \& Hakim, 2019).

\section{Teori Struktur Modal}

Profesor Franco Modigliani dan Merton Miller yang mengawali teori struktur modal modern pada tahun 1958 yang menunjukkan bahwasanya perusahaan dapat menggunakan cara apapun untuk membiayai kegiatan operasionalnya sehingga struktur modal menjadi tidak relevan (Brigham \& Houston, 2015, p. 466). Struktur modal merupakan pendanaan perusahaan yang bersumber atas hutang, modal pemegang saham dan saham biasa. Untuk memenuhi kebutuhan pendanaan dapat dengan pendanaan hutang yang didapat dari pinjaman maupun pembiayaan modal sendiri bersumber penerbitan saham.

\section{Harga Saham}

Harga saham menjadi parameter bagi investor saat pengambilan keputusan di masa yang akan mendatang. Adapun Indah dalam Tricia et al. (2018) mengatakan bahwa harga saham menggambarkan value dari sebuah perusahaan. Apabila perusahaan dapat mengoptimalkan kinerja perusahaannya dengan baik tidak menutup kemungkinan sahamnya akan banyak diminati investor. Harga saham ialah harga yang diperjualbelikan dalam pasar yang ditentukan oleh pelaku dari pasar tersebut (Widyaningrum \& Suwitho, 2020). Harga saham setiap saatnya mengalami pergerakan baik harga saham yang naik maupun turun dalam hitungan waktu sesuai dengan kondisi pasar modal.

\section{Profitabilitas dan Harga Saham}

Profitabilitas menggambarkan kapabilitas perusahaan untuk memperoleh keuntungan atau mengukur tingkat keefektifan pengoperasian manajemen perusahaan. Alat ukur yang digunakan adalah ROE (Return on Equity). ROE membandingkan laba setelah pajak dengan total ekuitas perusahaan. ROE yang semakin tinggi sudah tentu akan banyak pemodal yang merasa tertarik dan membuat meningkatnya harga saham. Dan sebaliknya semakin rendah ROE membuat hilang kepercayaan pemodal dan berdampak pada 
rendahnya harga saham. Dan penelitian tersebut sejalan dengan Cathelia \& Sampurno (2016), Sitorus \& Elinarty (2017), Batubara et al (2019), Saprudin (2019), Kamar (2017), Rahayu et al. (2020) dan Widajanto et al. (2021) yang menyatakan profitabilitas berpengaruh positif terhadap harga saham.

\section{Likuiditas dan Harga Saham}

Likuiditas menggambarkan kapabilitas perusahaan yang berkewajiban melunasi hutang lancarnya. Alat ukur yang digunakan adalah CR (Current Ratio). CR mengindikasikan perbandingan aset lancar dengan hutang lancar perusahaan. Meningkatnya CR menandakan perusahaan mengelola aktiva lancar dengan benar sehingga terdapat dana likuid yang dipergunakan untuk membayar hutang lancarnya. Hal itu menjadikan investor tertarik untuk berinvestasi dan membuat peminat saham tersebut meningkat maka berimbas pada naiknya harga saham (Andrean, 2019). Dan didukung oleh Hung et al. (2018), Rahayu (2020), Muhammad \& Rahim (2019), Latifah \& Suryani (2020) dan
Widyaningrum \& Suwitho (2020) menyatakan bahwa likuiditas berpengaruh positif terhadap harga saham.

\section{Leverage dan Harga Saham}

Leverage menggambarkan besaran kegiatan operasional perusahaan yang didanai dengan hutang. Alat ukur yang digunakan adalah DER (Debt to Equity Ratio). DER menggambarkan besaran kegiatan operasional perusahaan yang didanai bersumber dari utang perusahaan serta mengukur kemampuan perusahaan dalam melunasi hutangnya (Natalia et al., 2020). Peningkatan DER menunjukkan resiko yang dimiliki perusahaan atas tingkat pengembalian tinggi dan dapat membuat investor tertarik sehingga mempengaruhi harga saham (Ferriyanti \& Triyonowati, 2019). Dan penelitian tersebut didukung oleh Hanie \& Saifi (2018), Otekunrin et al. (2018), Ferriyanti \& Triyonowati (2019), Azmy \& Lestari (2019), Rachman et al. (2020) dan Natalia et al.(2020) yang menyatakan bahwa leverage berpengaruh positif terhadap harga saham.

\section{Model Penelitian Empiris}

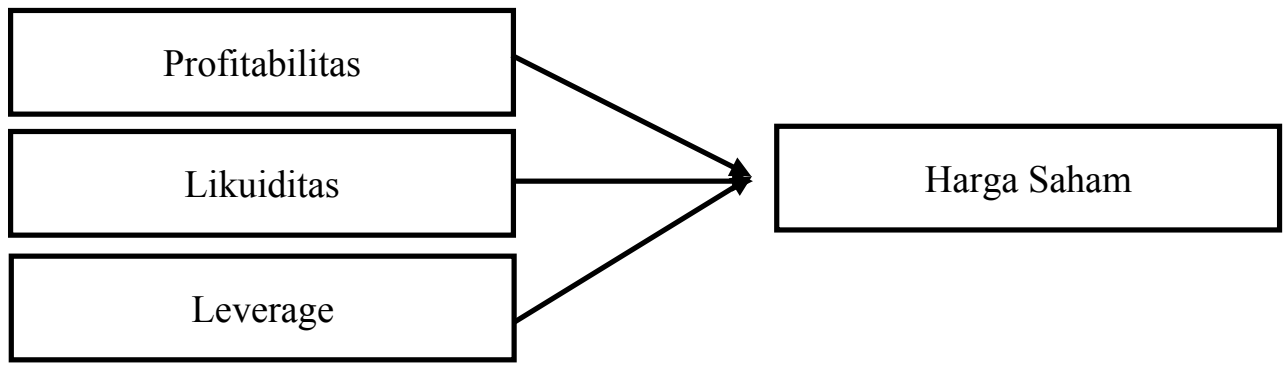

Gambar 1. Model Penelitian Empiris

\section{Hipotesis}

Berdasarkan kajian yang berhubungan dengan variabel dependen dan variabel independen serta model penelitian empiris diatas, maka terbentuklah hipotesis dalam penelitian seperti berikut:

$\mathrm{H}_{1}$ : Profitabilitas berpengaruh positif terhadap Harga Saham.

$\mathrm{H}_{2}$ : Likuiditas berpengaruh positif terhadap Harga Saham.

$\mathrm{H}_{3}$ : Leverage berpengaruh positif terhadap Harga Saham.

\section{METODA PENELITIAN}

\section{Populasi dan Sampel}

Seluruh perusahaan sektor aneka industri yang terdaftar di Bursa Efek Indonesia selama periode 2016-2019 merupakan populasi penelitian. Teknik pengambilan sampel mempergunakan metode purposive sampling. Berikut kriteria dan pertimbangan untuk menentukan sampel pertama, perusahaan sektor aneka industri yang terdaftar di Bursa Efek Indonesia selama periode 20162019. Kedua, perusahaan sektor aneka 
industri yang mempublikasikan laporan keuangan tahunan secara lengkap selama periode 2016-2019. Ketiga, perusahaan sektor aneka industri yang baru IPO (Initial Public Offering) selama periode 20162019. Terakhir, perusahaan sektor aneka industri yang tidak memperoleh laba selama periode 2016-2019.

\section{Pengukuran Variabel \\ Variabel Dependen (Y)}

Harga saham ialah harga pada saham terbentuk berdasarkan proses permintaan dan penawaran di pasar. Pada penelitian ini, menggunakan harga saham diukur dengan return penutupan rerata setiap akhir tahun. Berikut pengukurannya:

Return saham =

Harga saham tahun ini-Harga saham tahun sebelumnya Harga saham tahun sebelumnya

\section{Variabel Independen $(\mathbf{X})$ Profitabilitas $\left(\mathbf{X}_{1}\right)$}

Rasio Profitabilitas menggunakan Return On Equity (ROE). ROE menunjukkan kapabilitas perusahaan dalam menghasilkan laba bersih dari modal sendiri yang dimiliki perusahaan. ROE membandingkan laba setelah pajak dengan total ekuitas perusahaan. Berikut pengukurannya yang digunakan menggunakan satuan desimal:

$\mathrm{ROE}=\frac{\text { Laba Setelah Pajak }}{\text { Total Ekuitas }}$

\section{Likuiditas $\left(\mathbf{X}_{2}\right)$}

Rasio Likuiditas menggunakan Current Ratio (CR). CR mengukur kemampuan aset lancar terhadap hutang lancar untuk melunasi hutang lancarnya. CR membandingkan aset lancar dengan hutang lancar perusahaan. Berikut pengukurannya yang digunakan menggunakan satuan desimal:

$\mathrm{CR}=\frac{\text { Aset Lancar }}{\text { Hutang Lancar }}$

\section{Leverage $\left(\mathrm{X}_{3}\right)$}

Rasio Leverage menggunakan Debt to Equity Ratio (DER). DER mengindikasikan besaran kegiatan operasional perusahaan yang didanai bersumber dari utang perusahaan serta mengukur kemampuan perusahaan dalam melunasi hutangnya. DER membandingkan antara utang dengan ekuitas perusahaan.
Berikut pengukurannya yang digunakan menggunakan satuan desimal:

DER $=\frac{\text { Total Hutang }}{\text { Total Ekuitas }}$

\section{Teknik Pengumpulan Data}

Pada penelitian ini mempergunakan data sekunder, dengan metode kuantitatif. Sumber data berasal dari laporan keuangan perusahaan sektor aneka industri periode 2016-2019 yang berasal dari situs resmi www.idx.co.id maupun situs resmi masing-masing perusahaan sektor aneka industri yang akan diteliti.

\section{Teknik Analisis Data}

Teknik analisis data dalam penelitian mempergunakan bantuan program komputer software Eviews 11 dan Microsoft excel 2013 selain itu juga menggunakan analisis regresi data panel.

\section{Statistik Deskriptif}

Dalam penelitian ini, statistik deskriptif dengan menginterpretasikan data dalam bentuk tabel, grafik, persentase, standar deviasi dan lain-lain. Untuk menginterpretasikan data membutuhkan Profitabilitas (ROE), Likuiditas (CR) dan Leverage (DER).

\section{Model Regresi Data Panel}

Model persamaan regresi data panel sebagai berikut:

$$
\begin{aligned}
& \mathrm{Y}=\alpha+\beta 1 \mathrm{X} 1 \mathrm{it}+\beta 2 \mathrm{X} 2 \mathrm{it}+\beta 3 \mathrm{X} 3 \mathrm{it}+\mu \\
& \text { Keterangan }: \\
& \mathrm{Y} \quad=\text { Harga Saham } \\
& \alpha \quad=\text { Konstanta } \\
& \mathrm{X} 1 \quad=\text { Profitabilitas } \\
& \mathrm{X} 2 \quad=\text { Likuiditas } \\
& \mathrm{X} 3 \quad=\text { Leverage } \\
& \mathrm{b}(1 . .3)=\text { Koefisien regresi variabel } \\
& \text { independen } \\
& \mu \quad=\text { Error term } \\
& \mathrm{t} \quad=\text { Waktu } \\
& \mathrm{i} \quad=\text { Perusahaan }
\end{aligned}
$$

\section{Uji Hipotesis}

Pengujian hipotesis yang digunakan ialah Uji Parsial ( $t$ test) dan Uji Koefisien Determinasi $\left(\mathrm{Uji} \mathrm{R}^{2}\right)$

\section{HASIL DAN PEMBAHASAN}

Deskripsi Objek Penelitian 
Obyek pada penelitian ialah perusahaan sektor aneka industri yang terdaftar di Bursa Efek Indonesia periode 2016-2019. Berdasarkan 53 perusahaan sektor aneka industri, namun hanya 22 perusahaan yang termasuk kriteria sampel dengan periode penelitian selama 4 tahun. Maka dari itu, jumlah data keseluruhan sebesar 88 data sampel.

\section{Analisis Statistik Deskriptif}

Tabel 2. Hasil Statistik Deskriptif Eviews 11

\begin{tabular}{lcccc}
\hline & Harga Saham & ROE & CR & DER \\
\hline Mean & 0.328398 & 0.100169 & 2.409162 & 0.894136 \\
Median & 0.064500 & 0.072960 & 1.915045 & 0.665610 \\
Maximum & 9.641000 & 0.317830 & 6.777400 & 3.128760 \\
Minimum & -0.862000 & 0.000350 & 0.648610 & 0.101910 \\
Std. Dev. & 1.221712 & 0.081450 & 1.477246 & 0.680329 \\
Observations & 88 & 88 & 88 & 88 \\
\hline
\end{tabular}

Sumber: Output Eviews 11 (data diolah)

Bersumber pada tabel 2, menyajikan hasil pengolahan data dengan Eviews 11, adapun penjabaran dari statistik deskriptif adalah yang pertama, untuk variabel Harga Saham. Nilai rata-rata Return Saham sektor aneka industri pada 22 perusahaan sampel selama periode 2016 sampai dengan 2019 sebesar 0,328398 atau $32,83 \%$ yang mengartikan bahwa return yang didapatkan investor atas dana yang diinvestasikan pada saham perusahaan sektor aneka industri rata-rata sebesar $32,83 \%$. Perusahaan yang mempunyai nilai return saham tertinggi adalah PTSN sebesar 9,641000 pada tahun 2018. Sedangkan, terendah adalah PTSN sebesar $-0,862000$ pada tahun 2019. Standar deviasi dari return saham sebesar 1,221712 menunjukkan angka yang lebih besar dibanding nilai rerata hal tersebut menandakan ada kesenjangan di antara data return saham yang diolah.

Kedua, pada variabel Profitabilitas (ROE), nilai rata-rata Profitabilitas (ROE) sektor aneka industri pada 22 perusahaan sampel selama periode 2016 sampai dengan 2019 sebesar 0,100169 atau $10,01 \%$ yang mengartikan nilai ROE perusahaan sektor aneka industri termasuk dalam keadaan cukup baik karena masih berada pada standar penilaian $<15 \%$. Perusahaan yang mempunyai ROE tertinggi adalah SMSM sebesar 0,317830 pada tahun 2016. Sedangkan, terendah adalah UNIT sebesar 0,000350 pada tahun 2016. Standar deviasi dari ROE sebesar 0,081450 menyatakan angka yang lebih kecil dibanding nilai rerata hal tersebut menandakan adanya sedikit kesenjangan antara data ROE tertinggi dan terendah.

\section{Variabel Likuiditas (CR)}

Nilai rata-rata Likuiditas (CR) sektor aneka industri pada 22 perusahaan sampel selama periode 2016 sampai dengan 2019 sebesar 2,409162 atau $240,91 \%$ yang mengartikan nilai CR perusahaan sektor aneka industri termasuk dalam keadaan sangat baik karena masih berada pada standar penilaian 200\%-250\%. Perusahaan yang mempunyai $\mathrm{CR}$ tertinggi adalah IKBI sebesar 6,777400 pada tahun 2016. Sedangkan, terendah adalah UNIT sebesar 0,648610 pada tahun 2016. Standar deviasi dari CR sebesar 1,477246 menunjukkan angka yang lebih kecil dibanding nilai rerata hal tersebut menandakan adanya sedikit kesenjangan antara data CR tertinggi dan terendah.

\section{Variabel Leverage (DER)}

Nilai rata-rata Leverage (DER) sektor aneka industri pada 22 perusahaan sampel selama periode 2016 sampai dengan 2019 sebesar 0,894136 atau $89,41 \%$ yang mengartikan nilai DER perusahaan sektor aneka industri termasuk dalam keadaan baik karena masih berada pada standar penilaian $>70 \%-100 \%$. Perusahaan yang mempunyai DER tertinggi adalah PTSN sebesar 3,128760 pada tahun 2018. Sedangkan, terendah adalah INDS sebesar 0,101910 pada tahun 2019. Standar deviasi dari DER sebesar 0,680329 menyatakan angka yang lebih kecil dibandingkan nilai rataratanya hal tersebut menandakan adanya sedikit kesenjangan antara data DER tertinggi dan terendah. 


\section{Pemilihan Model Regresi Data Panel}

Dalam penelitian ini, struktur datanya mengoperasikan data panel. Pengujian model menggunakan bantuan Eviews 11 dan akan dilakukan sebanyak 2 kali yaitu uji Chow ( $F$ statistic) dan uji Hausman. Berikut pengujian modelnya:

\section{Uji Chow (F statistic)}

Uji Chow ( $F$ statistic) ialah pengujian yang dilakukan untuk menilai Common Effect Model (CEM) dengan Fixed Effect Model (FEM) mana yang lebih tepat. Berdasar Tabel 3, Cross-Section Chi-Square sebesar 0,0000 maka FEM yang paling tepat untuk penelitian ini.

Tabel 3. Hasil Uji Chow

\begin{tabular}{lrrr}
\hline Effects Test & Statistic & d.f. & Prob. \\
\hline Cross-section F & 3.775805 & $(21,63)$ & 0.0000 \\
Cross-section Chi-square & 71.697641 & 21 & 0.0000 \\
\hline Sumber : Oun
\end{tabular}

Sumber : Output Eviews 11 (data diolah)

\section{Uji Hausman}

Uji Hausman ialah uji model untuk menilai Common Effect Model (CEM) dengan Fixed
Effect Model (FEM) mana yang lebih sesuai untuk digunakan.

Tabel 4. Hasil Uji Hausman

\begin{tabular}{lrrr}
\hline Test Summary & Chi-Sq. Statistic & Chi-Sq. d.f. & Prob. \\
\hline Cross-section random & 34.547012 & 3 & 0.0000 \\
\hline
\end{tabular}

Sumber : Output Eviews 11 (data diolah)

Bersumber pada tabel 4, terihat nilai Cross-Section Chi-Square sebesar 0,0000 dimana nilai itu $(<0,05)$ menandakan $\mathrm{H}_{0}$ ditolak dan $\mathrm{H} 1$ diterima maka FEM yang paling tepat dalam penelitian ini.

\section{Model Regresi Data Panel Yang Digunakan}

Bersumber pada hasil pengujian Uji Chow dan Uji Hausman didapatkan Fixed Effect Model (FEM) yang paling sesuai untuk penelitian ini. Berikut model analisis regresi menggunakan FEM

Tabel 5. Fixed Effects Model (FEM)

\begin{tabular}{ccccc}
\hline Variabel & Coefficient & Std. Error & t-Statistic & Prob. \\
\hline C & -2.561200 & 0.536114 & -4.777339 & 0.0000 \\
Profitabilitas & 9.108827 & 2.850262 & 3.195785 & 0.0022 \\
Likuiditas & 0.119760 & 0.137367 & 0.871831 & 0.3866 \\
Leverage & 1.888587 & 0.373380 & 5.058080 & 0.0000 \\
\hline \hline
\end{tabular}

Sumber : Output Eviews 11 (data diolah)

Bersumber pada tabel 5, terlihat persamaan model regresi data panel dengan Eviews 11. Berikut persamaan regresi penelitian ini:

Harga saham $=-2,561200+9,108827$ $(\mathrm{ROE})+0,119760(\mathrm{CR})+1,888587(\mathrm{DER})$

Nilai konstanta sebesar $-2,561200$ menggambarkan apabila nilai dari variabel Profitabilitas (ROE), Likuiditas (CR) dan Leverage (DER) bernilai konstan atau nol maka
Return Saham perusahaan sektor aneka industri sebesar -2,561200.

Variabel Profitabilitas (ROE) mempunyai koefisien regresi yang menunjukkan arah positif sebesar 9,108827 artinya apabila nilai ROE meningkat dengan anggapan variabel lain tetap dan harga saham akan meningkat sebesar 9,108827. Sehingga dari koefisien menunjukkan hubungan positif antara $\mathrm{ROE}$ dengan harga saham. 
Variabel Likuiditas (CR) mempunyai koefisien regresi yang menunjukkan arah positif sebesar 0,119760 artinya apabila nilai CR meningkat dengan anggapan variabel lain tetap dan harga saham akan meningkat sebesar 0,119760. Sehingga, koefisien menunjukkan hubungan positif antara $\mathrm{CR}$ dengan harga saham.

Variabel Leverage (DER) mempunyai koefisien regresi yang menunjukkan arah positif sebesar 1,888587 artinya apabila nilai DER meningkat dengan anggapan variabel lain tetap dan harga saham akan meningkat sebesar 1,888587. Sehingga, koefisien menunjukkan hubungan positif antara DER dengan harga saham.

\section{Uji Hipotesis}

\section{Uji Parsial (t test)}

Adapun nilai $t_{\text {tabel }}$ dilihat melalui tabel statistik dengan tingkat signifikansi sebesar 0,05 . Df $=$ $\mathrm{N}$ (jumlah observasi) - $\mathrm{k}$ (jumlah variabel independen) -1 . Sehingga di dapat $\mathrm{df}=88-3$ $-1=84$ maka nilai $t_{\text {tabel }}$ sebesar 1,98861 . Adapun hasil uji parsial atau t test dengan Eviews 11:

Tabel 6. Hasil Uji Parsial (t test)

\begin{tabular}{ccccc}
\hline Variabel & Coefficient & Std. Error & t-Statistic & Prob. \\
\hline C & -2.561200 & 0.536114 & -4.777339 & 0.0000 \\
Profitabilitas & 9.108827 & 2.850262 & 3.195785 & 0.0022 \\
Likuiditas & 0.119760 & 0.137367 & 0.871831 & 0.3866 \\
Leverage & 1.888587 & 0.373380 & 5.058080 & 0.0000 \\
\hline
\end{tabular}

Sumber: Output Eviews 11 (data diolah)

Bersumber pada tabel 6 , pengaruh variabel independen terhadap variabel dependen dapat disajikan seperti berikut pertama, pengaruh profitabilitas (ROE) terhadap harga saham. Adapun hasil uji t, memperlihatkan nilai signifikansi Profitabilitas sebesar 0,0022<0,05 dengan nilai $t_{\text {hitung }}$ dan $t_{\text {tabel }}$ sebesar 3,195785>1,98861 menandakan $\mathrm{H}_{0}$ ditolak dan $\mathrm{H}_{\mathrm{a}}$ diterima mengartikan Profitabilitas berpengaruh positif terhadap Harga Saham.

Kedua, pengaruh likuiditas (CR) terhadap Harga Saham. Adapun hasil uji t, memperlihatkan nilai signifikansi Likuiditas sebesar $0,3866>0,05$ dengan nilai $t_{\text {hitung }}$ dan $t_{\text {tabel }}$ sebesar $0,871831<1,98861$ menandakan $\mathrm{H}_{0}$ diterima dan $\mathrm{H}_{\mathrm{a}}$ ditolak yang mengartikan Likuiditas tidak berpengaruh terhadap Harga Saham.

Ketiga, pengaruh leverage (DER) terhadap harga saham. Adapun hasil uji t, memperlihatkan nilai signifikansi Leverage sebesar $0,0000<0,05$ dengan nilai $t_{\text {hitung }}$ dan $t_{\text {tabel }}$ sebesar 5,058080>1,98861 menandakan $\mathrm{H}_{0}$ ditolak dan $\mathrm{H}_{\mathrm{a}}$ diterima yang mengartikan Leverage berpengaruh positif terhadap Harga Saham.

\section{Koefisien Determinasi (Uji $\mathbf{R}^{\mathbf{2}}$ )}

Hasil dari $\mathrm{Uji} \mathrm{R}^{2}$ terlihat pada nilai Adjusted R-Squared yang sebesar 0,451924 atau $45,2 \%$ mengartikan bahwa variabel Profitabilitas, Likuiditas dan Leverage dapat menjelaskan variasi dari variabel Harga Saham sebesar $45,2 \%$ dan sisanya sebesar $54,8 \%$ $(100 \%-45,2 \%)$ dapat dijelaskan dengan variabel lain selain variabel independen penelitian ini.

\section{PEMBAHASAN}

\section{Pengaruh Profitabilitas terhadap Harga Saham}

Dengan adanya hasil analisis uji t, diketahui bahwa Profitabilitas memiliki nilai $t_{\text {hitung }}$ dan $t_{\text {tabel }}$ sebesar 3,195785>1,98861 yang menunjukkan bahwa Profitabilitas berpengaruh dan menunjukkan arah positif terhadap Harga Saham maka $\mathrm{H}_{1}$ yang menyatakan Profitabilitas berpengaruh positif terhadap harga saham di terima dalam penelitian ini. Mengartikan apabila profitabilitas perusahaan sektor aneka industri meningkat tentu harga saham akan mengalami peningkatan, begitu sebaliknya. Berdasarkan hasil penelitian, perusahaan sektor aneka industri seperti AMIN, ASII, INDR, RICY, STAR, BATA, IKBI, VOKS dan PTSN membuktikan bahwa peningkatan profitabilitas dapat mempengaruhi peningkatan harga saham. Sebaliknya perusahaan BOLT, BRAM, INDS, SMSM, KBLI, KBLM dan SCCO membuktikan bahwa penurunan profitabilitas dapat mempengaruhi penurunan harga saham. 
Adapun hasil penelitian ini serupa dengan signalling theory yang menyatakan bahwa peningkatan profitabilitas dapat mengindikasikan perusahaan berhasil mengelola aset secara efisien sehingga tercipta kinerja perusahaan yang baik, dengan peningkatan profitabilitas juga dapat menyampaikan sinyal positif bagi investor untuk dijadikan pertimbangkan dalam membuat keputusan pembelian saham. Semakin besar profit yang dihasilkan maka akan meningkat keuntungan investor. Hal tersebut akan meningkatkan permintaan atas saham dan membuat harga saham naik (Latifah \& Suryani, 2020). Sebaliknya apabila profitabilitas perusahaan mengalami penurunan menandakan kinerja perusahaan yang kurang baik dan dapat ditangkap investor sebagai sinyal negatif sehingga membuat terjadinya aksi jual saham yang dapat berpengaruh ke harga saham perusahaan tersebut.

Berdasarkan uraian diatas, kesimpulannya adalah Profitabilitas berpengaruh positif terhadap Harga Saham. Temuan penelitian ini persis dengan Andrean (2019), Saprudin (2019), Meryati (2020), Pratama (2020), Siregar \& Sihombing (2020), Rahayu et al., (2020) dan Widajanto et al., (2021).

\section{Pengaruh Likuiditas terhadap Harga Saham}

Dengan adanya hasil analisis uji t, diketahui bahwa Likuiditas memiliki nilai $t_{\text {hitung }}$ dan $t_{\text {tabel }}$ sebesar $0,871831<1,98861$ yang menunjukkan bahwa Likuiditas tidak berpengaruh terhadap Harga Saham maka $\mathrm{H}_{2}$ yang menyatakan Likuiditas berpengaruh positif terhadap harga saham tertolak dalam penelitian ini. Hasil penelitian adalah bahwa peningkatan maupun penurunan likuiditas tidak mempengaruhi peningkatan maupun penurunan harga saham perusahan sektor aneka industri. Hal ini karena likuiditas perusahaan sektor aneka industri selama periode penelitian menunjukkan penurunan atau peningkatan yang tidak diiringi dengan penurunan atau peningkatan dari harga saham dan tidak berpengaruh. Berdasarkan hasil penelitian, perusahaan sektor aneka industri seperti AMIN, ASII, BOLT, BRAM, INDS, INDR, PBRX, JECC, KBLM, SCCO, VOKS dan PTSN maka membuktikan bahwa peningkatan maupun penurunan likuiditas tidak mempengaruhi harga saham.

Adapun hasil penelitian ini menggambarkan beberapa investor yang melakukan investasi tidak memperhatikan nilai CRnya karena peningkatan nilai $\mathrm{CR}$ yang semakin tinggi tidak selalu berarti baik bisa jadi menandakan perusahaan tersebut memiliki terlalu banyak aset lancar atau adanya kas yang besar mampu memenuhi hutang lancarnya (Mustaffa \& Syabani, 2021). Namun, beberapa investor lain berasumsi aset lancar yang terlalu banyak membuat kas menganggur akibatnya perusahaan tidak dapat mengoptimalkan kegiatan perusahan dalam menghasilkan laba (Andrean, 2019).

Berdasarkan penjelasan tersebut, maka kesimpulannya adalah Likuiditas tidak berpengaruh terhadap Harga Saham. Temuan ini serupa dengan Adipalguna \& Suarjaya (2016), Pangestuti \& Hamidi (2016), Widayanti \& Colline (2017), Faleria et al., (2017), Otekunrin et al., (2018) Lilie et al., (2019) dan Indrayani et al., (2020).

\section{Pengaruh Leverage terhadap Harga Saham}

Dengan adanya hasil uji $t$, memperlihatkan nilai $t_{\text {hitung }}$ dan $t_{\text {tabel }}$ sebesar $5,058080>1,98861$ yang menunjukkan bahwa Leverage berpengaruh terhadap Harga Saham dengan arah positif menandakan $\mathrm{H}_{3}$ yang menyatakan Leverage berpengaruh positif terhadap harga saham diterima dalam penelitian ini. Mengartikan apabila nilai DER perusahaan sektor aneka industri meningkat maka harga saham tentu mengalami peningkatan, begitu sebaliknya. Berdasarkan hasil penelitian, perusahaan sektor aneka industri seperti AUTO, BOLT, BRAM, INDS, SMSM, PBRX, RICY, SRIL, UNIT, IKBI, KBLI, SCCO dan VOKS maka membuktikan bahwa peningkatan maupun penurunan leverage akan mempengaruhi harga saham.

Berdasarkan hasil pada penelitian ini mengindikasikan peningkatan maupun penurunan leverage mempengaruhi harga saham. Sejalan dengan teori yang ada dalam Latifah \& Suryani (2020) bahwa manajemen menginformasikan sinyal mengenai kinerja perusahaan melalui besaran antara hutang dan modal. Peningkatan nilai DER yang semakin tinggi digunakan untuk menambah modal atas 
hutang untuk membiayai kegiatan operasional perusahaan. Jika perusahaan mengelola hutang dengan tepat serta dapat memperoleh profit yang besar hal tersebut dapat memberikan investor berupa sinyal positif agar dapat melakukan pembelian saham. Sehingga, banyaknya permintaan akan saham membuat harga saham meningkat. Namun, saat perusahaan gagal mengelola hutang dengan baik maka akan sampai kepada investor menjadi sinyal negatif.

Berdasarkan penjelasan diatas, maka kesimpulannya adalah Leverage berpengaruh positif terhadap Harga Saham. Temuan ini serupa dengan Pangestuti \& Hamidi (2016), Hanie \& Saifi (2018), Otekunrin et al., (2018), Tantri \& Djawoto (2019), Ferriyanti \& Triyonowati (2019), Natalia et al., (2020), Anjayagni \& Purbawati (2020) dan Rachman et al.,(2020).

\section{SIMPULAN}

Bersumber pada hasil pembahasan serta rumusan masalah yang ada, maka ditarik simpulan seperti: 1) Variabel Profitabilitas dengan Return on Equity menunjukkan bahwa Profitabilitas berpengaruh terhadap Harga Saham perusahaan sektor aneka industri yang

\section{DAFTAR REFERENSI}

Adipalguna, I. G. N. S., \& Suarjaya, A. A. G. (2016). "Pengaruh Likuiditas, Solvabilitas, Aktivitas, Profitabilitas, Dan Penilaian Pasar Terhadap Harga Saham Perusahaan LQ45 Di BEI." E-Jurnal Manajemen Unud, 5(12), 7638-7668. Retrieved from https://garuda.ristekbrin.go.id/documents /detail/1370314

Andrean, M. E. (2019). "Pengaruh Likuiditas, Leverage dan Profitabilitas Terhadap Harga Saham Pada Perusahaan Property dan Real Estate Yang Terdaftar Di Bursa Efek Indonesia Tahun 2014-2018."

Anjayagni, P., \& Purbawati, D. L. (2020). "Pengaruh CR (Current Rasio), DER (Debt to Equity Rasio), dan TATO (Total Assets Turn Over) Terhadap Harga Saham (Studi Pada Perusahaan Sub Sektor Farmasi di Bursa Efek Indonesia Periode 2015-2018)." Jurnal Ilmu terdaftar di Bursa Efek Indonesia tahun 20162019 sehingga dapat menjadi tolak ukur investor untuk berinvestasi. 2) Variabel Likuiditas dengan Current Ratio menunjukkan bahwa Likuiditas tidak berpengaruh terhadap Harga Saham perusahaan sektor aneka industri yang terdaftar di Bursa Efek Indonesia tahun 2016-2019 sehingga tidak dapat menjadi tolak ukur investor untuk berinvestasi. 3) Variabel Leverage dengan Debt to Equity Ratio menunjukkan bahwa Leverage berpengaruh positif terhadap Harga Saham perusahaan sektor aneka industri yang terdaftar di Bursa Efek Indonesia tahun 2016-2019 sehingga dapat menjadi tolak ukur investor untuk berinvestasi.

Adapun keterbatasan penelitian yang mungkin dapat mempengaruhi hasil dari penelitian ini, seperti penggunaan sampel penelitian yang relatif sedikit dari 53 perusahaan sektor aneka industri yang dapat dipergunakan hanya 22 perusahaan dikarenakan 31 perusahaan lain tidak memenuhi kriteria sampel. Maka dari itu, untuk penelitian selanjutnya diharapkan dapat memperluas sampel penelitian agar mendapatkan hasil penelitian yang bervariasi.

Administrasi Bisnis, 9(3), 224-231.

Aristanti, R. D., \& Utiyati, S. (2018). "Pengaruh NPM, DER, CR dan EPS Terhadap Harga Saham Pada Perusahaan Transportasi." Jurnal Ilmu Dan Riset Manajemen, 7(10).

Azmy, A., \& Lestari, A. (2019). "Analisis Pengaruh Rasio Keuangan Terhadap Harga Saham Perusahaan Re \& Properti Di Indonesia." Jurnal Riset Manajemen Sains Indonesia (JRMSI), 10(2). https://doi.org/doi.org/10.21009/JRMSI.0 10.2.01

Batubara, H. C., Astuti, D. D., \& Ramadani. (2019). "Pengaruh Current Ratio dan Return On Equity Terhadap Price Earning Ratio Pada Perusahaan Manufaktur Sub Sektor Makanan dan Minuman yang Terdaftar Di Bursa Efek Indnesia (BEI) Periode 2013-2017." Seminar Nasional Inovasi Produk Penelitian Pengabdian Masyarakat \& Tantangan Era Industri 4.0, 2(1), 104-116. Banda Aceh: LPPM Universitas Serambi Mekkah. 
Brigham, E. F., \& Houston, J. F. (2015). Fundamentals of Financial Management, Concise Eighth Edition (8th Editio).

Cathelia, N., \& Sampurno, R. D. (2016). "Analisis Pengaruh ROE, DER, TATO, CAPEX Dan NCCR Terhadap Harga Saham (Studi Kasus pada Perusahaan Manufaktur Sektor Industri Barang Konsumsi yang terdaftar di Bursa Efek Indonesia Periode 2010-2014)." Diponegoro Journal of Management, 5(3), 1-13.

Ferriyanti, E., \& Triyonowati. (2019). "Pengaruh Profitabilitas, Solvabilitas dan Pertumbuhan Penjualan Terhadap Harga Saham." Jurnal Ilmu Dan Riset Manajemen STIESIA Surabaya, 8(1), 120.

Hanie, U. P., \& Saifi, M. (2018). "Pengaruh Rasio Likuiditas dan Rasio Leverage Terhadap Harga Saham Studi Pada Perusahaan Indeks LQ45 Periode 20142016. Jurnal Administrasi Bisnis (JAB), 58(1), 95-102.

Hastuti, N., \& Sutanto, A. (2017). "Analisis Pengaruh Rasio Keuangan Terhadap Harga Saham Pada Perusahan Otomotif Yang Tercatat Di Bursa Efek Indonesia (BEI) Periode 2012-2014." Jurnal Fokus Manajemen Bisnis, 7(2), 144-155. https://doi.org/https://doi.org/10.12928/fo kus.v7i2.1743

Hung, D. N., Ha, H. T. V., \& Binh, D. T. (2018). "Impact of Accounting Information on Financial Statements to the Stock Price of the Energy Enterprises Listed on Vietnam's Stock Market." International Journal of Energy Economics and Policy, 8(2), 1-6.

Janiman, J. (2021). "Pengaruh Dividend Payout Ratio Dan Debt To Equity Ratio Terhadap Price Earnings Ratio." Syntax Literate: Jurnal Ilmiah Indonesia, 6(2), 837-852. https://doi.org/http://dx.doi.org/10.36418/ syntax-literate.v6i2.2166

Kamar, K. (2017). "Analysis of the Effect of Return on Equity (Roe) and Debt to Equity Ratio (Der) On Stock Price on Cement Industry Listed In Indonesia Stock Exchange (Idx) In the Year of 20112015." IOSR Journal of Business and Management, 19(05), 66-76. https://doi.org/10.9790/487X-

\section{6}

Latifah, H. C., \& Suryani, A. W. (2020). "Pengaruh Kebijakan Dividen, Kebijakan Hutang, Profitabilitas, dan Likuiditas Terhadap Harga Saham." Jurnal Akuntansi Aktual, 7(1), 31-44. https://doi.org/10.17977/um004v7i12020 p31

Meryati, A. (2020). "Pengaruh Faktor Fundamental Terhadap Return Saham Serta Dampaknya pada Nilai Perusahaan Otomotif di Indonesia." JIMF (Jurnal Ilmiah Manajemen Forkamma), 3(3), 283-295.

https://doi.org/10.32493/frkm.v3i3.5413

Muhammad, T. T., \& Rahim, S. (2019). "Pengaruh Tingkat likuiditas Dan Profitabilitas Terhadap Harga Saham Pada Perusahaan Manufaktur Yang Terdaftar Di Bursa Efek Indonesia (BEI)." Jurnal Akuntansi Akmal, 3(2), 117-126.

Natalia, N., Putri, A. P., Melvina, M., Jenni, J., \& Wijaya, K. (2020). "Pengaruh MVA, DER, Serta EPS Terhadap Harga Saham Perusahaan Restoran, Hotel dan Pariwisata." Owner (Riset Dan Jurnal Akuntansi), $\quad 4(2), \quad 616$. https://doi.org/10.33395/owner.v4i2.307

Nurlia, \& Juwari. (2019). "Pengaruh Return On Asset, Return On Equity, Earning Per Share Dan Current Ratio Terhadap Harga Saham Pada Perusahaan Sub Sektor Otmotif Dan Komponen Yang Terdaftar Di Bursa Efek Indonesia." Jurnal GeoEkonomi, 10(1), 57-73. https://doi.org/https://doi.org/10.36277/g eoekonomi.v10i1.50

Otekunrin, A. O., Nwanji, T. I., Egbide, B. C., Fakile, S. A., Ajayi, S. A., Falaye, A. J., ... Eluyela, D. F. (2018). "Profitability Ratios And Market Price Of Share Of Selected Firms In Quoted Nigeria Agriculture And Agro-Allied Firms: After Adoption Of International Financial Reporting Standard." Proceedings of the 32nd International Business Information Management Association Conference, IBIMA 2018 - Vision 2020: Sustainable Economic Development and Application of Innovation Management from Regional Expansion to Global Growth, 4, 63996411. 
https://doi.org/https://doi.org/10.32861/js sr.412.736.744

Pangestuti, D. C., \& Hamidi, A. (2016). "Pengaruh Faktor Fundamental Perusahaan Terhadap Harga Saham Di Bursa Efek Indonesia." Jurnal Manajemen Ilmu Ekonomi Dan Bisnis, $3(1), 1-14$.

Pratama, R. (2020). "Analisis Profitabilitas Dan Leverage Terhadap Return." Judicious; Journal of Management, 1(2), 91-101. https://doi.org/https://doi.org/10.37010/jd c.v1i2.131

Priliyastuti, N., \& Stella, S. (2017). "Pengaruh Current Ratio, Debt To Asset, Debt To Equity, Return on Assets dan Price Earnings Ratio terhadap Harga Saham." Jurnal Bisnis Dan Akuntansi, 19(5), 320324.

Rachman, Y. T., Rachmat, R. A. H., \& Oktaviani, A. S. (2020). "The Impact of Earning Per Share (EPS), Return on Assets (ROA) and Debt To Equity Ratio (DER) on Stock Price (Empirical Study in Automotive Sub Sector Manufacturing Companies and Components Listed in Indonesia Stock Exchange (IDX) Period 2015-2019)." PalArch's Journal of Archaeology of Egypt/Egyptology, 17(10), 3083-3093.

Rahayu, N. A. (2020). "Pengaruh Current Ratio (CR), Return On Asset (ROA), Earning Per Share (EPS) Terhadap Harga Saham Pada Perusahaan Manufaktur Sub Sektor Otomotif Dan Komponen Yang Terdaftar Di Bursa Efek Indonesia Periode 20132017." Jurnal Manajemen Inovasi, 10(2), 50-64.

https://doi.org/10.24815/jmi.v10i2.15997

Rahayu, R., Siswantini, T., \& Triwahyuningtyas, N. (2020). "FaktorFaktor yang Mempengaruhi Harga Saham (Studi Kasus: Aneka Industri yang Terdaftar di BEI)." Konferensi Riset Nasional, Manajemen Dan Akuntansi I, 1162-1176. Universitas Pembangunan Nasional Veteran Jakarta.

Saprudin. (2019). "Pengaruh Kepemilikan Managerial, Leverage dan Profitabilitas Terhadap Harga Saham Perusahaan Manufaktur." Journal of Information System, Applied, Management, Accounting and Research, 3(3), 19-26.
Saprudin, \& Hasyim, T. M. (2020). "Pengaruh Profitabilitas dan Leverage terhadap Harga Saham Perusahaan Manufaktur di Bursa Efek Indonesia." Majalah Sainstekes, 7(1), 58-66.

Setiawanta, Y., \& Hakim, M. A. (2019). "Apakah Sinyal Kinerja Keuangan Masih Terkonfirmasi? : Studi Empiris Lembaga Keuangan di PT. BEI.” Jurnal Ekonomi Dan Bisnis, 22(2), 289-312. https://doi.org/10.24914/jeb.v22i2.2048

Siregar, M. R. A., \& Sihombing, P. (2020). "Determinant Analysis of Financial ratio On Stock Returns In Construction Companies Registered At Indonesia Stock Exchange 2015-2019." International Journal of Education and Social Science Research Management And Social Science, 2(1), 67-80. https://doi.org/10.31933/DIJEMSS

Sitorus, T., \& Elinarty, S. (2017). "The Influence of Liquidity and Profitability Toward The Growth of Stock Price Mediated By The Dividen Paid Out (Case in Banks Listed in Indonesia Stock Exchange)." Journal of Economics, Business \& Accountancy Ventura, 19(3), 377-392. https://doi.org/10.14414/jebav.v19i3.582

Sudana, I. M. (2015). Manajemen Keuangan Perusahaan: Teori \& Praktik (Edisi 2). Jakarta: Erlangga.

Tantri, E. N., \& Djawoto. (2019). "Pengaruh Profitabilitas, Leverage Dan Likuiditas Terhadap Harga Saham Pada Perusahaan Manufaktur Sub Sektor Food And Beverage Yang Terdaftar Di Bursa Efek Indonesia." Jurnal Ilmu Dan Riset Manajemen (JIRM), 8(10), 1-17.

Tricia, Y. E., Surachim, A., \& Tarmedi, E. (2018). "Gambaran Likuiditas, Profitabilitas Dan Harga Saham Pada Perusahaan Otomotif Yang Terdaftar Di BEI." Journal of Business Management Education (JBME), 3(2), 11-20. https://doi.org/https://doi.org/10.17509/jb me.v3i2.14210

Wangarry, A. R., Karamoy, H., \& Gamaliel, H. (2019). "Pengaruh Konservatisme, Dividend Payout Ratio, Tingkat Likuiditas Aset, dan Leverage Terhadap Harga Saham Pada Perusahaan Manufaktur." Jurnal Riset Akuntansi Dan 
Auditing "Goodwill," 10(1), 1-13. https://doi.org/10.35800/jjs.v10i2.24869

Widajanto, G. R. T., Ediwarman, \& Desmintari. (2021). "Analisis Harga Saham Perbankan Yang Terdaftar Di Bursa Efek Indonesia." Konferensi Riset Nasional Ekonomi Manajemen Dan Akuntansi, 2(1), 1307-1322.

Widayanti, R., \& Colline, F. (2017). "Pengaruh Rasio Keuangan Terhadap Harga Saham
Perusahan LQ 45 Periode 2011-2015." Bina Ekonomi, 21(1), 35-49. https://doi.org/https://doi.org/10.26593/b e.v21i1.2622.35-49

Widyaningrum, T. P., \& Suwitho. (2020). "Pengaruh ROE, CR dan EPS Terhadap Harga Saham Perusahaan Otomotif Di BEI." Jurnal Ilmu Dan Riset Manajemen, 9(3).

\section{Copyrights}

Copyright for this article is retained by the author(s), with first publication rights granted to the journal.

This is an open-access article distributed under the terms and conditions of the Creative Commons Attribution license (http://creativecommons.org/licenses/by/4.0/). 